to the State of Bhopal, Central India. He returned to India in 1955 at the invitation of the Covernment of India to inquire into matters touching the development of the lac industries. In fact, he is widely travelled (another recent journey having been to Brazil to advise on organized research in paint and related matters) and is well known internationally, for example, through his work for the Organic Coatings Division of the Applied Chemistry Section of the International Union of Pure and Applied Chemistry.

Dr. Jordan has given extensive service to the Oil and Colour Chemists Association (he was president during 1947-49) and to numerous other scientific and technical organizations. $\mathrm{He}$ was chairman of the council of the Society of Chemical Industry during 1952-53 and medallist of the Society in 1953 . As one of the Jubilee Memorial lecturers of the Society (1944) he chose as his subject "Paint, the Art and Science", reflecting his interest in the artistic as well as in the industrial and scientific aspects of paint and painting, an interest culminating in 1958 in his appointment as professor of chemistry at the Royal Academy of Arts. His work for technical education stands high in achievement and personal satisfaction. He has for long been chairman of the City and Guilds Advisory Committee on Paint 'Technology, and his period as a Surrey county councillor (1946-58) provided opportunities for contributions in a wider field of technical studies. $\mathrm{He}$ is now chairman of the governors of the Kingston Technical College, a governor of the Brunel College of Technology, and a member of the Regional Advisory Council for Technological Education for London and the Home Counties Region. He has recently been appointed to the senate of the University of London.

\section{Botany at Hull :}

Prof. R. D'O. Good

Prof. Ronald Good, who has retired from the chair of botany in the University of Hull, was head of the Department of Botany from the foundation of the University College in 1928. After serving in the First World War, followed by a brilliant period at Downing College, Cambridge, he held an appointment at the British Museum (Natural History). At Hull he had much to do with the organization and equipment of his department, as well as teaching, but he has also been active as a researcher and writer. His book on the "Geography of the Flowering Plants" has had a wide circulation and is regarded as one of the chief works on the subject, while his "Handbook of the Dorset Flora" is an outstanding ecological study.

\section{Prof. N. F. Robertson}

Dr. N. F. Robertson, who has succeeded Prof. Good, has been on the staff of the Cambridge Botany School since 1948. His interest in mycology was first aroused by Dr. Malcolm Wilson at the University of Edinburgh. After graduating there in 1944, Dr. Robertson was appointed a Colonial Office probationer and studied at the University of Cambridge, at Rothamsted Experimental Station and in the United States before proceeding to the West African Cacao Research Institute at Tafo late in 1946. He worked there, in collaboration with Dr. A. F. Posnette, on insect transmission of the swollen shoot disease. Dr. Robertson's first research problem at Cambridge was concerned with mycorrhizal infection of the Scots pine, and he made a notable contribution to the subject by showing that the behaviour of the mycor- rhizal fungus was closely related to that of the specialized root disease fungi affecting tree crops. More recently, Dr. Robertson has turned his attention to the physiology of fungal branch systems in culture, and has made what may eventually prove to be the first experimental approach to the morphogenesis of asexual spore production. With his research students, Dr. Robertson has explored a much wider field, ranging from the physiology and geneties of the Fusaria in laboratory experiments to the behaviour of Fusarium wilt diseases and potato blight in the field. The University of Hull is doubly fortunate in securing Dr. Robertson as professor of botany, because he has distinguished himself at Cambridge not only by his research but also as a teacher, and by the full share he has taken in other duties in the Department of Botany, where he will be greatly missed.

\section{The World Veterinary Association :}

Prof. W. I. B. Beveridge

AT the recent International Veterinary Congress in Madrid a World Vetorinary Association was established. The main purposes of the Association are to unify the veterinary profession throughout the world by providing a central link for national veterinary associations, and the exchange of information on matters of veterinary interest. The organs of the Association are the congress and the permanent committee.

Prof. W. I. B. Beveridge, professor of animal pathology, University of Cambridge, has boen elected president of the Permanent Committee of the newly founded World Veterinary Association. He has had a distinguished career as a veterinarian who gavo outstanding service to his profession in Australia and in the United Kingdom. After graduating at the University of Sydney, he was a member of the research staff of the MeMaster Animal Health Laboratory in Sydney during 1931-41. During two years of that time he was the holder of a Commonwealth Fund Fellowship at the Rockefeller Institute, Princeton, and the Bureau of Animal Industry, Washington. From 1941 until his appointment as professor of animal pathology in Cambridge he worked at the Walter and Eliza Hall Institute in Melbourne. Together with Sir Macfarlane Burnet ho worked on viral diseases in man and published several outstanding paper's concerning cultivation of viruses. In Cambridge, Prof. Beveridge's researches are mainly concerned with viral diseases of respiratory systems in animals. Unfortunately, his scientific work there was very much interrupted by administrative duties associated with the establishment of tho new Veterinary School which was opened by H.M. the Queen and the Duke of Edinburgh in October 1955. $\mathrm{He}$ is the author of the book, "The Art of Scientific Investigation". Both on account of his outstanding reputation and his interest in international co-operation, he will be a most welcome president of the newly founded World Veterinary Association.

\section{Amendments to the U.S. Atomic Energy Act}

IN a report by the United Statos Atomic Energy Commission (The Indemnification of Atomic Energy Activities and Operations of Advisory Committee on Reactor Safeguards, 1958-59. Report of the Joint Committee on Atomic Energy on Operations under Section 170 of the Atomic Energy Act of 1954 as Amended. Pp. iii +74 . Washington, D.C. : United 